scale joint task. It is logical to assume that in teaching mechanics it will be useful to follow the historical sequence of development of concepts and ideas that arose in the process of development of ideas and evolution of mechanics. There is a good reason to believe that, when studying the concepts of mechanics in such a way, students will face a minimum of difficulties, i.e. there is a minimum of energy spent on learning and a multiplicative effect, if this were not the case, then the evolution of mechanics as a whole would go the other way.

Key words: evolution, mechanics, mathematical model of phenomenon, information theory, dialectical interaction, multiplicative effect.

UDC 372.881.111.1

Iryna Lobachova

SHEE "Donbas State Pedagogical University"

ORCID ID 0000-0001-7102-1915

DOI 10.24139/2312-5993/2019.05/120-131

\title{
SOME ASPECTS OF FORMING STUDENT POSITIVE MOTIVATION TO LEARN FOREIGN LANGUAGES
}

The article deals with the problem of forming student positive motivation to learn foreign languages. In the research the following ways of student motivation are proposed: encourage students to visualize their success; implement all the learning styles; use individual methods for every student; take the class beyond the classroom walls; tell students expectations and standards for learning; change in style and authority; give rewards to students; be firm with the class, etc. The ways for keeping students motivated while teaching a foreign language (let students know aims and objectives of learning; give learners what they need; present directions for learning; recognize work well done; personalize teaching; use team building activities; support practicality in actions, etc.) are offered. In further articles it is planned to consider innovative methods and means in teaching foreign languages in higher education institutions.

Key words: motivated student, encourage, foreign language learning activity, communicative situation, teaching methods, motivation, praise, learning style, teambuilding.

Introduction. Motivation in learning English plays a great role for mastering the foreign language material. For intellectual activity it is necessary to take into account that conscious external motivation (e.g. a sense of responsibility, duties in society, a motive of own well-being, mastering a foreign language for the future career; or a lack of desire to learn, realizing own failure due to a lack of language knowledge, etc.) and the internal one (e.g. availability and practicality of an educational material, topic variety, methods, techniques and means of informing) help to stimulate students' speech and mental activity, their thoughts and cause a desire to learn more and think in a foreign language. It creates positive conditions for learning a foreign language. It should be mentioned that without taking into account these factors, student speech activity becomes detached from real points of view, thoughts, interests, i.e. it loses a source that activates speech activity. 
Analysis of relevant research. An important contribution to the study of the problem of motivation in teaching a foreign language is made by J. Catapano, T. Dawe, L. Davies, A. Markova, T. Matis, T. Kharchenko and others. The issue of implementing the innovative multimedia technologies while studying English is considered by both native and foreign scholars: I. Zymnia, S. Nikolaieva, T. Pakhomova, Yu. Hapon, V. Liaudis, E. Nosenko and others. Such psychologists, scientists and teachers as V. Acieiev, Yu. Babanskyi, I. Bekh, I. Vasyliev, D. Elkonin, A. Leontiev, S. Rubinshtein, L. Slavina and others state that the most important aspect of modern education is forming learning motivation. The analysis of literary and scientific sources confirms lack of complex studying of the mentioned problem and the need to research some aspects.

Aim of the study. The aim of research is to consider the problem of forming student positive motivation to learn foreign languages; to propose a number of ways to motivate learners; to give tips on effective teaching English and suggest methods for encouraging students in learning a foreign language.

Research methods. Taking into account the specifics of the aim such methods as pedagogical observation, study, analysis and generalization of pedagogical experience, literary and scientific sources are used in this study. It allowed obtaining reliable data and making full conclusions; getting to the essence of the outlined problem and passing logically from the general idea to specific one.

Results. Increasing international relations of Ukraine provide internationalization of all aspects of public life. A foreign language is necessary in different fields of human activity. It is an effective factor in socio-economic, scientific-technical and general cultural development of society.

Learning English is a difficult and lengthy process that requires patience, strong concentration and to feel confidence in its successful completion. In order to achieve serious learning results, every student needs motivation, in fact without it the initial enthusiasm passes very quickly and studying the language turns into a routine.

Therefore, when students begin to master the language, they must clearly recognize needs and opportunities that can be opened before them. Knowing language helps to develop intellectual potential, expand the world view, professional growth, respect and recognition among friends and colleagues.

One of the strongest motivation factors for continuing language learning is awareness of future prospects. In fact nothing does not motivate so perfectly, as a positive result in performing any activity. Gradually, progress will become more noticeable, and further learning will only be a pleasure. 
Mastering the material performs faster with each new lesson, and, therefore, learning the language will be more effectively.

It is important to remember that motivation is a powerful psychological tool, because it helps not to stop moving forward, but to persevere towards a goal and to overcome all the difficulties in learning English.

Motivation is interests, needs, aspirations, emotions, persuasions, ideals, settings that encourage learners to work. Motivation promotes student learning initiative and love to study, encourages to act with maximum energy in different learning situations. In the methodological literature there are lots of theories of learner motivation, but for the teacher it is important to master the ways to create such learning environment in which students feel an internal need to learn.

It is found out that even the best students have days when they are not motivated for learning. So, the main teacher's purpose is to turn this routine into successful activity in their perspectives. In this research such ways to motivate students today are proposed.

1. Encourage students to visualize their success. Learners perform expectations that everyone around them communicate. It does not imply that every student will be excellent on every test is done. It means that if teachers tell students that they are failure, they will fail. If teachers tell the same students that they will succeed, such result will be found. At every stage of the study a teacher should encourage students that they are making progress in their language learning. Show them the areas in which you see progress and improvement of knowledge. For fields in which a student efforts, try to depict a situation of what success will look like. Encouraging students to visualize their success will aid them in accomplishing goals a teacher set before them.

2. Implement all learning styles. Another way to motivate students is to be sure we are teaching to all learning styles in lessons. It is incredible to expect learners to be successful and motivated if the only instruction comes from reading a coursebook. Also, a kinesthetic learner will be frustrated listening to a teacher's lecture class after class. Make sure, as you plan your lessons that you implement all learning styles in the classroom. If you follow this item, you will engage learners who might otherwise struggle to pay attention in lessons (Dawe, 2018).

3. Bring additional resources to the class. Motivating students is as simple as changing learning materials. As a rule, education institutions choose a curriculum that is expected to follow by every teacher at lessons. If it is true, it does not mean that a teacher cannot use additional resources in a class. Learners are sometimes tired by the styles or approaches of proposed curriculum of authors. Implementing new resources into the lesson will re-engage students who 
are tired by certain learning materials. Also it will motivate those learners who are already having success in the appointed curriculum.

4. Use individual methods for every student. When a student is outside the class, it's a good opportunity for a teacher to analyze what means, methods and techniques were implemented in the lesson. Although some activities may be good for most learners, there will be students who do not interact with these means and methods and who feel uncertainty when a teacher uses them in a lesson. If it happens think of the methods which are used and look for alternative. Despite of some difficulties that exist in the classroom of foreign language learners, a teacher can take efforts to avoid such methods when it is possible to help students doing better at lessons. Also it will help a teacher to be deliberate about using an amount of methods in the class and further involving all of them (Catapano, 2017).

5. Take the class beyond the classroom walls. Changing learning environment can also be the thing that reluctant learners need to feel new motivation. Trips made by students to study something at first hand are always a good idea to learn in a practical way, but if that is not possible, a teacher can take students outside the class (e.g. a class meeting in the gallery; cinema; library; bank; café; shop, etc.). It is found out that daily class aims are achieved even if the teacher takes students outside the class. Organize students to research at the library, communicate at the cinema (café; shop, etc.), or listen to native foreign speakers in public places (e.g. public organizations for studying foreign languages). A foreign language to be learned and mastered always exists, so meet learner's speaking, listening, and reading aims outside the education institution walls.

6. Tell students your expectations and standards for learning. Giving students responsibilities in learning is an important factor of teaching foreign languages. Without knowing information on terms and evaluation, many learners would never have self-motivation that is required for learning a language successfully. A teacher must be well-defined with students telling them expectations for learning. It is important to be sure that learners know terms for a project's ending and a system of evaluating this project. The teacher may also determine prospective assessments with students who have more advanced level (Teach Thought Staff, 2017). When a teacher and students clarify features of evaluation they sign an agreement that defines the requirements for receiving "excellent" and "good". It is noteworthy that the teacher should not give requirements for lower assessments. The learners choose which mark to receive in the class and then they have to perform proper requirements completely. From the beginning of studying students know what they need to achieve and they 
recognize that their success fully depends on themselves. This fact will help learners to be self-motivated and involve themselves into learning activity.

7. Change style and authority. Some students have stressful behavior when they come to a lesson. For some teachers they misconduct constantly, but a skilled teacher can help them to cope with this uncertainty, can break learners out of this state by bringing fresh impacts into the class (e.g. inviting native speakers; changing classes for a period with a fellow teacher; holding TED-talks conference or teleconference, etc.). Changing style and authority, even for a short time, may be enough to bring some motivation to students who get used to teacher's style and perspectives (Catapano, 2017).

8. Use the spirit of competition. Another method to motivate learners is implementing the spirit of competition. It does not mean to inform students about their marks publicly or otherwise embarrassing them, but there are lots of ways to encourage a friendly spirit of competition among learners. For example, a teacher can use games for revision learning materials, motivating and involving students into studying foreign languages; or can also group learners into teams and put challenge. It is important to use the right level of challenge, i.e., offer a variety of fun and challenging activities. Who can make a music video or design a poster to explain a grammar point? Which team can find the most original examples of the studied grammatical structure in texts of fiction? Who can write the most amusing essay with topic vocabulary or deliver a speech? So, the teacher has lots of opportunities to create the spirit of competition into learning activity.

9. Give rewards to students. As a rule, giving rewards is also the motivational method for learners. A teacher should tell students about praising them, if the most of them get higher marks on a test or write essays successfully they will go to the cinema, café, pizzeria, have a picnic in the forest, park or on the river bank, etc. Sometimes for keeping learner's motivation it can be enough to use a sticker as a smile on a student's copybooks. To praise students the teacher can design special rewards according to learner's personality. It is always pleasant for students to get assessments for well done work, and all rewards are enjoyable things for great success (Davies, 2018).

10. Be firm with the class. It is proved that means of positive motivation are more effective for stimulating students to foreign language activities. However, do not forget about negative motivation. Students usually study well not because of the fear of punishment, but because they like to do it or their responsible attitude to learning activity, that is, because of self-motivation. But sometimes it is impossible to perform without punishment. When student selfmotivation is low and methods of encouraging do not work, it is necessary to 
appeal to punishment as to the extreme degree of influence on the unmotivated learner, and thus impact both on one student and indirectly on other students (e.g. keep students (a group) after classes; talk to student's parents if it is possible and necessary, etc.). Negative motivation is most needed where there are clear rules that require control. The peculiarity of negative motivation is that not the desire to achieve something better forces the student to act, as in positive motivation, but the desire to avoid trouble. So, negative means of motivation perform indirectly. In addition, means of punishment are demonstrative and therefore impact both on the unmotivated student and the whole class.

Everyone who studies foreign languages recognizes that teachers work hard to help their students to master languages fluently and have progress in their language learning. Teachers develop curriculum, present teaching materials in enjoyable, creative and engaging ways and try to use different practical language tasks. But sometimes it means nothing if students are unmotivated for learning. So, it is very important to involve students into their own language activities. In this research it will be proved that motivating students is easier than it might be. It is proposed some effective ideas for learners that can show the difference between students who don't care of their knowledge and ones who are really eager to change their own education.

Dealing with a group of motivated students is much easier and more interesting but it is also a great work for a teacher. So, the teacher should follow such tips for keeping students motivated.

1. Let students know aims and objectives of learning. Creating a syllabus curriculum at the beginning of studying is that teachers have to do in any case. For some teachers it helps to organize lessons in a planned way. If a foreign language is taught to learners at initial stage, a written syllabus may not be the best way for interaction between a teacher and students, but the teacher can still let learners to know directions of language learning. Actually the teacher can give them this information using mind mapping for each lesson. If it is necessary, create a weekly or monthly mind map in the classroom with aims and objectives for learning (Lobachova, 2016, p. 315). Such actions will help students to recognize what a teacher expects of them each day. When learners know teacher's perspective, they are more likely to involve into learning activity and feel a sense of achievement those goals are met, and this fact will increase students' motivation to do well in the classroom.

2. Present directions for learning. It should be mentioned that to know only rules and tasks but not to know how to use them is not enough to perform such activities, that is, students must have directions for actions. So, as soon as the plan 
and the proper resources are chosen and demonstrated, a teacher needs to show learners the way to act. When students interact in their native language, such act of communication performs without conscious efforts. But it does not happen when learners communicate in a foreign language because they have to think about their actions and what they say and how they use a foreign language. So, a teacher's aim in foreign language teaching is to show students the mechanism of language work and encourage them to implement their knowledge. Sometimes learners will not know how to use the techniques a teacher has made available in the lesson until they will not be shown. Instead of proposing general tasks (e.g. do exercises on proper tense or right grammatical construction, on prepositions of place, time, etc.), skilled teachers present their students clearly where to search such exercises. The teacher mostly offers specific language tasks and showing learners useful Internet resources, successful learning methods and effective ways to practice foreign language skills will help students to perform well in this activity. Also the teacher can suggest them the list of scientific books and journals, channels, TV programs, shows or podcasts that will be easy to understand and help learners to improve language skills. So, students will feel more confident in their activity and it will help them in foreign language studying when they recognize correctness of their own actions. Thus, learners will be more motivated to continue these activities and perform others proposed by the teacher (Teach Thought Staff, 2017).

3. Propose students what they need for studying. To let students know aims and perspective of learning is a good idea, but this information will not help learners if they don't have proper resources for successful activity in the lesson. So, it is necessary to have the right methods and environment for students. A teacher cannot expect students to do well at listening activity if there are no any listening resources for such studying, or if learners have not got books (e-books, the Internet) as information materials they will not be able for constructive research. It is proved that to provide students' needs a teacher can take them to the library or invite English speakers to create foreign language environment. Before each lesson the teacher should think and inform students about their achievements. Also learners have to know about what they need to accomplish these objectives. In addition, the mind map should be created for successful and complete students' learning activity. If teachers follow these instructions, learners will avoid disappointment and stay more motivated in their language learning.

4. Think about your learning style. It is known that the most motivated students always feel their importance in learning activities and teachers make everything possible for their studying. It depends on teacher learning styles. 
The specific approach to every student has great importance because not all learners have the same success and study the same way in proposed learning activity planned for them. That's why using as many different learning styles as possible in lessons will give the teacher the most motivated students. It means that it is necessary to think about learners who require different approaches and methods for learning. When students know that the teacher makes efforts to satisfy everyone's learning needs, they will respond with mutual actions and become the most knowledgeable learners (Lobachova, 2016, p. 320).

5. Personalize your teaching. Personalized approach and tasks modifications can do a lot when it concerns students' motivation. Despite the number of students in the class, there will always be those who will be interested in achieving a high level of knowledge. Teaching students on their own the teacher has to show that he/she is worried about their successes and is ready to go together through all the difficulties of learning. When it is possible, spend time to each learner during the lesson. The teacher can do this while other students perform independent or group work. During individual work with each learner the teacher should find out what is difficult for them and offer to help solving complicated tasks. Personalized approach to each learner might also mean spending time outside of the classroom (Dawe, 2018). The teacher can propose after classes help to students who need it. It indicates that teachers take care of their learners. The teacher can use modifying tasks or make homework easier or flexible to help students achieve success. It is important to get creative with tasks modifications and encourage learners to share their opinions. It does not mean that teachers have to accept all of their thoughts, but by interacting the teacher should be able to choose a decision pleasant for both of you.

6. Make a group effort. It is known that every student in the classroom also plays a responsible role in motivating other learners. There are students in the class who are worried about the skills of their speech, about its permanent improvement, but there are those who are concerned only with assessments. The teacher should try to unite (to form the most effective groups and teams perhaps according to similar aims and attitudes, skill levels, etc.) these groups for working productively together, it will help learners to motivate one another. In any case, involving students into group activities and encouraging them to help each other in foreign language learning will play an essential role in learning activity. It also means that the teacher should propose these kinds of activity where learners will need their partner to complete the task successfully. This group work should also be evaluated. This way may be just motivation for those students who need to focus on the given task. 
7. Recognize work well done. Despite the course of student studying to praise them telling that they do the right thing means a lot. It is proved that students, no matter how old they are, will be nice to hear words of praise for their work well done or a positive assessment of their activities. When learners know that their actions are appreciated by teachers and help them to reach set aims, they are more motivated to enhancing efforts in the prospect career. When students do something right, teachers will be able to praise students in many effective ways (e.g. do it with words "Excellent", "Well done", "Good job", etc.; to praise individually or in front of the whole class or other groups of the institution, etc.). It is necessary to comment classwork, homework, tests, essays and projects got from students. It will not only enhance confidence of students, but also give them some experience that they can see and recognize their achievements. And also students will want to get positive comments on future tasks (Teach Thought Staff, 2017).

8. Use team building activities. Implementing team building activities is another way to keep students motivated. This activity is specially organized work aimed at uniting students, forming a strong spirit for successful achievements of any goals. The teacher should encourage learners to build friendships with their coursemates by including team building activities in learning. When students have support directly in the classroom, they will become stronger and be able to overcome all difficulties that rise before them. When there are students in the class who do not build quickly relationships with their coursemates, the teacher can try to match them with those who, in his/her opinion, will succeed in learning. The teacher should stress on importance of friendships and have fun with one another both in the classroom and out of lessons. This will help students to feel themselves one big family, to raise the spirit of mutual respect, relations and help and to achieve success in foreign language learning.

9. Support practicality in actions. The teacher should show learners how the language that they know or learn has practical application for their prospective career. Also teachers have to stress on perspective development of personality in learning foreign languages and to emphasize how English can make our life easier and change it. The motivational aspect can be the statement such as English for a job and professional growth: to get well-paid job; read professional literature in the original and use English-language sites; find business partners, investors, customers at international exhibitions; take part in international conferences, seminars and trainings, where high-level professionals discuss the latest trends in different fields, share experience and consider future perspectives about development, etc. (Dawe, 2018). English will be useful in everyday life and 
will give an opportunity to get an education of an international level; move to live abroad; watch films in English, deeper understand the plot of the film, listen and understand English-language songs; play games, use applications and computer programs in English; make purchases in international online stores, etc. So, when teachers make practical student activity and show learners how their success will help them in real life, students will see a lot of perspectives and study more consciously. When learners recognize their present efforts getting success in the future, they will work hard in their English learning.

Conclusions. Choice of the most appropriate methods, forms and means of organizing learning activity, effective combining and consistency of using, creating the most favorable conditions, team and individual methods of teaching English are basis for the formation of positive students' motivation, enable acquisition of the original foreign language learning material and go beyond proposed information.

In the article the following ways of motivating students are considered: motivating success through constructive communication; using traditional and innovative teaching methods while teaching a foreign language; individual approach (teaching method) to each student; engaging life communication situations; determining clear terms and levels of language learning for students; changing the teaching style in the class to uncover students' hidden potential; prediction of the final result.

Advice on active English learning for motivated students is given: 1) encourage students to visualize their success; 2 ) implement all the learning styles; 3) use individual methods for every student; 4) bring additional resources to the class; 5) engage life communication situations; 6) take the class beyond the classroom walls; 7) tell students expectations and standards for learning; 8) change in style and authority; 9) use the spirit of competition; 10) give rewards to students; 11) be firm with the class.

The ways for keeping students motivated while teaching a foreign language are offered: 1) let students know goals and objectives of learning; 2) give students what they need; 3) present direction for learning; 4) think about your learning style; 5) recognize work well done; 6) personalize teaching; 7) make a group effort; 8) use team building activities; 9) support practicality in actions.

In further articles it is planned to consider innovative methods and means in teaching foreign languages in higher education institutions.

\section{REFERENCES}

Лобачова, І. (2016). Імплементація концептуальних карт для підвищення іншомовної комунікативної компетентності майбутніх фахівців. Педагогічні науки: теорія, історія, інноваційні технології, 2 (56), 315-321 (Lobachova, I. (2016). 
Implementation of concept maps to improve foreign communicative competence of prospective specialists. Pedagogical sciences: theory, history, innovative technologies, 2 (56), 315-321).

Catapano, J. (2017). How to Motivate Students with Encouragement. Retrieved from: http://www.teachhub.com/how-motivate-students-encouragement

Davies, L. (2018). Rewards in the Classroom. Retrieved from: http://www.kellybear.com/TeacherArticles/TeacherTip45.html

Teach Thought Staff. (2017). 21 Simple Ideas To Improve Student Motivation. Retrieved from: https://www.teachthought.com/pedagogy/21-simple-ideas-to-improve-studentmotivatio/

Dawe, T. (2018). How to Motivate and Encourage Students. Retrieved from: https://www.education.gov.gy/web/index.php/teachers/tips-forteaching/item/1320-how-to-motivate-and-encourage-students

\section{АНОТАЦІЯ}

Лобачова Ірина. Умови формування позитивної мотивації студентів до вивчення іноземних мов.

У статmі розглянуто низку способів мотивації студентів до вивчення іноземної мови. 3'ясовано, що використання практично корисних методів, прийомів $і$ засобів організації навчальної діяльності, їхнє доцільне поєднання, створення найбільш сприятливих умов, застосування командних та індивідуальних форм роботи в навчанні англійської мови $\epsilon$ підгрунтям для формування позитивної мотивації студентів. Такий підхід дозволяє забезпечити ефективне засвоєння оригінального іншомовного матеріалу та підтримати зацікавленість у вивченні іноземної мови. Доведено, що мотивація студентів залежить від чітко окреслених цілей, нагальних потреб, кар'єрного зростання, мотивів, заохочення, опосередкованого впливу викладача та застосування тих навчальних методів, які найбільше сприяють мотивації.

Мета розвідки - дослідити проблему формування позитивної мотивації студентів у вивченні іноземних мов; запропонувати шляхи заохочення студентів до вивчення англійської мови та способи підтримки мотивації в навчальній діяльності.

Ураховуючи специфіку мети, у статті використано такі методи дослідження, як педагогічне спостереження, вивчення, аналіз та узагальнення педагогічного досвіду i літературно-наукових джерел, що дозволило зробити грунтовні висновки й дістатися до сутності окресленої проблеми.

Розглянуто такі шляхи мотивації студентів щодо ефективного вивчення англійської мови: заохочувати студентів до візуалізації їхнього успіху; використовувати всі можливі стилі навчання; застосовувати індивідуальні методи навчання; залучати додаткові навчальні ресурси; практикувати життєві ситуачії спілкування; організовувати навчальну активність за межами аудиторії; чітко визначати терміни й рівні вивчення мови; прогнозувати кінцевий результат; змінювати стиль навчання в аудиторії, щоб розкрити прихований потенціал студентів тощо).

Запропоновано способи підтримки мотивації студентів під час викладання іноземної мови: дозволити студентам знати цілі та завдання навчання; дати їм те, що потрібно; показати напрями в навчанні; відзначити успіхи та добре виконану роботу; персоналізувати навчання; використовувати тімбілдинг; скеровувати студентів на практичне застосування здобутих знань тощо).

У подальших дослідженнях заплановано розглянути інноваційні методи та засоби навчання іноземних мов у звО. 
Ключові слова: умотивований студент, заохочення, іншомовна навчальна діяльність, комунікативна ситуація, методи навчання, мотивація, нагорода, стиль навчання, тімбілдинг.

\section{PEЗЮME}

Лобачева Ирина. Условия формирования положительной мотивации студентов к изучению иностранных языков.

В статье рассмотрен ряд способов мотивации студентов к изучению иностранного языка. Определены инструкции по эфрективному обучению английскому языку и предложены пути побуждения студентов к иноязычной учебной деятельности. Выяснено, что мотивация студентов зависит от определенных целей, насущных проблем, карьерных перспектив, поощрения, мотивов, опосредованного воздействия преподавателя и использования всего арсенала учебных средств, наиболее способствующих мотивации. Доказано, что использование различных методов, фрорм и средств организации учебной деятельности, создание благоприятных условий во время обучения английскому языку способствуют формированию положительной мотивации студентов и позволяют обеспечить эфрфективное усвоение аутентичного иноязычного материала.

Ключевые слова: мотивированный студент, поощрение, иноязычная учебная деятельность, коммуникативная ситуация, методы обучения, мотивация, награда, стиль обучения, тимбилдинг.

УДК 372.46(493)

Олена Мартиненко

Сумський державний педагогічний

університет імені А. С. Макаренка ORCID ID 0000-0002-8287-0573

Ярослав Чкана

Сумський державний педагогічний

університет імені А. С. Макаренка

ORCID ID 0000-0003-3667-3584

DOI 10.24139/2312-5993/2019.05/131-139

\section{ВИКОРИСТАННЯ ГЛОСАРІЮ ПРИ ФОРМУВАННІ ІНФОРМАЦІЙНОЇ КОМПЕТЕНТНОСТІ ІНОЗЕМНИХ СТУДЕНТІВ ПРИ НАВЧАННІ МАТЕМАТИЧНИХ ДИСЦИПЛІН У ПЕДАГОГІЧНИХ УНІВЕРСИТЕТАХ}

у статті досліджено важливі аспекти формування інформаційної компетентності іноземних студентів при навчанні математичних дисциплін у педагогічних університетах. Обгрунтовано дочільність упровадження білінгвального навчання при формуванні інформаційної компетентності іноземних студентів; описано методичні особливості використання в навчальному процесі словника математичних термінів (глосарію) як однієї з форм білінгвізму. Виділено складові інформаційної компетентності студентів фізико-математичного фракультету педагогічного університету та схарактеризовано рівні їі сформованості. 